\title{
The Enlightenment from the Experience of the Construction of Vietnamese Socialist Legal Power
}

\author{
Fengming $\mathrm{Zhu}^{1}$ \\ ${ }^{1}$ School of Marxism, Qilu University, No. 2 Wenbo Road, Zhangqiu District, Jinan City, Shandong Province, \\ China
}

Keywords: Viet Nam; Socialism; Jurisdictional States

\begin{abstract}
The construction of Vietnam's socialist jurisdiction is a useful exploration of how to develop democratic politics under the one-party rule of the Communist Party. It has achieved preliminary results. China must grasp the breakthrough points and advantages in the construction of Vietnam's socialist jurisdiction and draw lessons from its experience. We will promote socialism with Chinese characteristics and promote democracy and the rule of law. Thus, the National governance system and governance capacity will eventually be modernized.
\end{abstract}

The construction of the socialist legal power country in Vietnam adheres to the principle of "party leadership, people's ownership, and state management." We are building a socialist rule of law. China is adhering to the basic principle of "the party's leadership, the people being the masters of the country, and the rule of the country." . Although the construction of the socialist legal power of Vietnam has its own characteristics and is different from China's specific national conditions and party conditions, China and Vietnam are still connected in the same way in terms of national construction goals and principles. There is great similarity in Vietnam's socialism. In a certain sense, the construction of the country of legal power also provides experience and enlightenment for the current comprehensive rule of law in China.

\section{Cultivating Citizens' Modern Rule of Law}

Since the reform and opening up, Vietnam has taken the goal of building a socialist legal power, and implemented the core of the rule of law, which has the core role of the mind, in the process of nation building, paying special attention to the construction of the rule of law culture and focusing on strengthening the rule of law. For our country, only the spirit of the rule of law is deeply rooted in the hearts of the people. Everyone from the heart supports the legal authority and consciously abides by the law. People from all walks of life strictly follow the provisions of the Constitution and the law, so that the law can be implemented into all aspects of real life and form a way for everyone to know. Good legal atmosphere for learning, law, law and usage. This will not only promote the progress of civilization in society, but also help to promote the implementation of China's comprehensive strategy of governing the country according to law.

\subsection{Focus on civic education.}

Civic education is the foundation of socialist rule of law in China. Although the civic awareness has improved with the acceleration of the construction of the country under the rule of law in China, the stereotypes still exist due to the influence of the feudal historical traditions of our country for thousands of years. The traditional rule of man and customs and cultural concepts are still stubborn. At the moment, we must firmly grasp the grasp of school education, and carry out a gradual and progressive civic awareness to help citizens rationalize their understanding of the complex relationship between individuals, organizations and social institutions, between rights and powers, between democracy and the rule of law. Awareness of civil rights.

\subsection{Cultivate the concept of the supremacy of law.}

Facing the historical tradition of China's rule of virtue and rule of the people and the modern rule 
of law is the reality of imported goods, we must actively promote the rule of law education and propaganda, promote the rule of law and build the legal culture with the respect of personal values and the "people-oriented" concept. To improve the initiative and enthusiasm of the rule of law, actively fill the historical defects of the lack of the rule of law, strive to realize the people's recognition and recognition of the "good law", and consciously regard the law as the standard and norm of its own words and deeds, and form a law-abiding glory in the whole society. The good atmosphere of violating the law and shame has made the broad masses of the people become loyal advocates, conscious adherents and staunch defenders of the socialist rule of law.

\subsection{We need to build a sound institutional mechanism.}

First of all, the measures to improve the spirit of the rule of law are institutionalized, its institutional carrier is improved, and through the operation of the system, people's lives are affected, and then internalization is a kind of value recognition of society and individuals, and finally habits are formed. The second is to optimize the supervision, restriction and feedback mechanism, make a timely and effective legal evaluation, make a consistent positive evaluation of the law compliance, and investigate the violations of the law without mercy, and form a good rule of law effect.

\section{Achieving Positive Interaction between Democracy and the Rule of Law}

Japanese-American scholar Francis Fukuyama once put forward the "political three-dimensional theory," that is, the real political development is the balance between national construction, the rule of law and democracy. Democracy and the rule of law are two sides of the same coin, and they are inseparable. In the relationship between democracy and the rule of law, on the one hand, the rule of law is the foundation of democracy. The rule of law establishes the institutional framework for democratic politics and regulates and regulates it. In the process of social transformation, it is empty talk about democracy without the rule of law. If the rule of law is not established, democracy will be established. This will be a joke and a disaster. On the other hand, democracy provides a guarantee for the Advancement of the rule of law. Democracy is the foundation of the rule of law, and there is no real rule of law in the soil of autocracy. Only in a Democratic environment can the rule of law exist and develop.If the internal link between democracy and the rule of law is separated, it will not only delay the development and modernization of the country, but also may lead to the construction of socialist democracy and the rule of law in the right direction. In 2014, the Fourth Plenary Session of the 18th CPC Central Committee set out the overall goal of comprehensively advancing the rule of law and made new arrangements for strengthening the socialist rule of law. Building a socialist state under the rule of law has become a social consensus. Reasonable reference to the beneficial experience of democratic reform in the construction of Vietnam's socialist state will help us broaden our thinking on comprehensively deepening reform, achieve a benign interaction between democracy and the rule of law, and modernize China's National governance system and capacity for governance. Finally, the cause of jointly promoting the building of a moderately prosperous society in an all-round way is rolling forward.

\section{Focus on Debugging of Internal and External Factors}

The construction of any right country can not be separated from the guidance of the construction of the world's right country. For historical and other reasons, Viet Nam has always been under the influence of foreign colonial forces. In the long-term development process after Hejianguo's struggle for national independence, Vietnam's study of foreign ideas, cultures, and institutions is also one of its main characteristics, and the thought, culture, and institutions of the rule of law are also included. The rule of law is the prosperity of the country, and the rule of law is strong. To realize the Chinese dream of the great renewal of the Chinese nation, China must follow the path of comprehensive rule of law with Chinese characteristics in the new era. It must not only rely on its own national conditions, but also draw on the successful experience of other countries. In order to 
better build a strong, prosperous, democratic, civilized, harmonious and beautiful socialist modern power.

\subsection{We must rely on national conditions.}

The path of democracy and the rule of law in a country must be adapted to the basic conditions of the country. The experience of history has proved time and time again that, in order to govern the country in an all-round way and build a socialist country under the rule of law, we must never completely westernize it or copy the fruits of other people. In the new era, the road of comprehensive rule of law with Chinese characteristics must be rooted in the Chinese land on which we rely for survival and development, and we must realize that China is now in the primary stage of socialism and will be in the long-term. We also need to take into account a wide range of factors, such as large population, weak economic foundation, unbalanced development and different national qualities, give full play to China's characteristics and advantages, and take the only correct road to building socialism with Chinese characteristics as the rule of law.

\subsection{We should draw on the experience of other countries.}

While learning from our successes, we must not lose sight of the hard lessons. First of all, we must prevent copying and copying in learning, put an end to "bringing in doctrine" and not engage in "making it whole." Since modern times, learning, learning and transplanting are the main channels for the construction of the rule of law in China, mainly referring to the legal system of the West or the Soviet Union. In the early days of the founding of New China, under the influence of the "one-sided" foreign policy, we copied the Soviet model without principle, and lingered between human rule and the rule of law, which greatly affected the process of building a socialist China under the rule of law. Second, we must also abandon the "one size fits all" inheritance, eager to break down the dilapidated legal system, establish a new legal system, completely break the relationship between the old and new legal systems, interrupt the historical inheritance of the old and new laws, and abandon the favorable elements of the old laws.

\section{Strengthening the Party's Leadership in Building the State of Socialist Legal Power}

We will strengthen the Party's leadership in building a territorial state and give priority to building its own jurisdiction. The drastic changes in the Soviet Union and the East in 1991 caused the socialist cause to suffer heavy losses. Its painful historical lessons tell us that only the Communist Party's firm control over the leadership of socialism can make socialism prosperous and the people's profits endless. In the long term of government, the Communist Party of Vietnam has realized that strengthening the right to jurisdiction is the ultimate shortcut to socialist development, and that the Vietnamese Communist Party must first improve its own legal system in order to lead the construction of a socialist country. This is the deciding factor to ensure the success of Viet Nam's socialist jurisdiction. The CPC, as the core of leadership in the cause of socialism with Chinese characteristics, is the choice of history and the people, and it is also an inevitable choice to govern the country by law. The CPC is a well-deserved core of leadership, and its leadership is the fundamental guarantee of the rule of law. It is the key to determine the success or failure of the rule of law in China.Without the leadership of the Communist Party of China to rule the country according to law, we will not succeed without abandoning our previous efforts and deviating from the main line. The leadership of the Party is the essential feature of the rule of law in China and the most important symbol of the rule of law in Western countries. In the modern state operation, the rule of law and political parties are inseparable. The rule of law adjusts the relations between the party and government and regulates the way of governing, while the ruling party needs the rule of law to achieve and consolidate the ruling position. China is a one-party country. The leadership of the Party and the rule of law are closely related and related. The two are the same. The socialist rule of law must adhere to the leadership of the Communist Party of China. The leadership of the Party provides strong support for the construction of the rule of law. The leadership of the Communist Party of China must also rely on the socialist rule of law to provide security for the party's 
leadership.The dialectical relationship between the leadership of the CPC and the rule of law, which is inseparable and highly unified, objectively prompts us to clearly recognize the form and deal with the relationship between the two, and resolutely resist, correct and eliminate the erroneous understanding that separates or even opposes the relationship. Looking at the history of our country's development since the founding of New China, especially since the reform and opening up, it is not difficult to find that the rule of law is the great and correct choice made by the CPC in its long practice. Historical experience has proved that only by adhering to the Party's leadership in ruling the country by law and implementing the leadership of the Communist Party of China into the whole process and all aspects of the overall rule of law, can the building of a socialist country under the rule of law in all respects proceed in depth and depart from the leadership of the Communist Party of China. The building of a socialist state governed by the rule of law is nothing but empty talk.To build socialist rule of law China is not to weaken the leadership of the CPC, nor to shake it, but to strengthen and adhere to the leadership of the CPC in an all-round way, to improve the leadership ability and level of governance of the $\mathrm{CPC}$, and to ensure that the CPC has a high level of leadership and rule of law.

\section{Adhere to the Main Position of the People}

In Viet Nam's process of socialist jurisdiction, it adheres to the basic principles of the main body of the people, implements the principle of "belonging to the people, coming from the people, for the people", pursues the supremacy of the people, and regards people's sovereignty as the ultimate goal and core value of socialist state construction. Since the founding of the Party in 1921, the Communist Party of China has taken the realization of the people as masters of the country as its goal, led the Chinese people to establish the People's Republic of China, and implemented the people's Congress system and the People's Political Consultative Conference system after the founding of the People's Republic of China. In the new era, we need to comprehensively govern the country according to law and promote the socialist construction of a law-based China. We need to give full expression to the will of the people and safeguard their interests. We will carry out the status of the people as the main body in every link of the rule of law and promote its implementation in the practice of comprehensive rule of law.

First,we will improve the ways, means and systems for people's participation in the rule of law. We need to give full play to the role of NPC deputies in drafting and amending laws, broaden the means for citizens to participate in legislation in an orderly manner, improve the mechanism for public consultation on draft laws and regulations, build consensus in society, and increase people's participation. The people are guaranteed to manage state and social affairs in accordance with the law. Second, we need to strengthen legislation in key areas to guarantee citizens 'rights. We will promote the rule of law in democratic politics, institutionalize laws to guarantee and improve people's livelihood, strengthen the process of building consultative democracy, ensure democracy at the grassroots level, and standardize public services. We will ensure that the people's rights and interests in education, employment, income and distribution, health care, social security and social assistance are fairly reflected, and that the legitimate rights and interests of women, children, the disabled and the elderly are effectively protected by law.Third, ensure the implementation of the people's right of supervision. Through the implementation of the people's Congress system, and the people's extensive exercise of the right of supervision, prosecution, litigation, media supervision, judicial supervision, etc., to supervise the power of the government, the judiciary and other organs and all aspects of society to ensure the status of the people. Fourth, we should enrich social life at the grassroots level, increase the participation of grass-roots social organizations of the people, and enable the people to reflect their main position in directly participating in self-government, democratic consultation, and formulating rules for the people's conventions.

\section{References}

[1] Nguyen, Hai Hong, "Grassroots Democracy and Inequality Reduction in Rural Vietnam: The 
Case of Thái Bình in 1997 and Now”, Asian Journal of Political Science, 02 January 2014, Vol.22 (1), p.71-92.

[2] Grossheim, Martin, "The Lao Động Party, Culture and the Campaign against 'Modern Revisionism'. The Democratic Republic of Vietnam Before the Second Indochina War”, Journal of Vietnamese Studies, February 2013, Vol.8 (1), pp.80-129.

[3] Lokshin, Grigory, "Vietnam: A New Stage in Renewing the Party and the Country”, Far Eastern Affairs, Apr-Jun 2011, Vol. 39(2), pp.97-106.

[4] Lokshin, Grigory, “The Ideas of Ho Chi Minh in Vietnam's Foreign Policy”, Far Eastern Affairs, Jul-Sep 2015, Vol. 43(3), p.16.

[5] Amer, Ramses, Vietnam in 2010, Asian Survey, Jan/Feb 2011, Vol. 51(1), pp.196-201. 